STUDIA PRAWNO-EKONOMICZNE, T. CIX, 2018

PL ISSN 0081-6841; e-ISSN 2450-8179 S. 73-86

https://doi.org/10.26485/SPE/2018/109/5

\title{
FAILURE TO ENSURE LEGAL CERTAINTY AS A BASIS FOR DAMAGE CLAIMS. A LEGAL AND COMPARATIVE ANALYSIS
}

\begin{abstract}
(Summary)
The article discusses the issue of a relationship between the failure to ensure legal certainty related to reasonable and legitimate expectations and possible claims for damages lodged by private entities against the host country. The changes in the system of regulation of investments in wind power plants in Poland which affected the profitability of such ventures were an impulse for analysing this issue. The presentation of changes in the regulatory environment of wind power plants in Poland combined with an analysis of changes in the methods of acknowledgement of liability for damages in French law may result in very interesting conclusions for both the Polish legislators and private operators engaged in wind power generation. The French jurisprudence and doctrine may provide a wider spectrum of potential legal grounds for compensation claims in the this field and provide an impulse for further more detailed analysis.
\end{abstract}

Keywords: wind farm; future damage; French law; compensation; legal certainty JEL classification: K33

\section{Introduction}

This article analyses the problem of a relationship between the failure to ensure legal certainty (and resulting reasonable and legitimate expectations) and possible claims for damages lodged by private entities against the host state. An impulse for researching this issue were changes in the system of regulation of investments in wind power plants in Poland. A sudden change in the legal

* Ph.D., assistant professor in UWM in Olsztyn, Faculty of Law and Administration, Department of Civil Law II and Economic Law; e-mail: m.krzykowski.mk@gmail.com

** Ph.D., assistant professor in UWM in Olsztyn, Faculty of Law and Administration, Department of Financial Law; e-mail: michal.marianski@uwm.edu.pl 
background may, from the perspective of numerous operators, result in a loss underlain by the general lack of legal certainty in the energy sector.

The case of wind power plants in Poland prompts a reflection on the legal basis for claims for damages based on the non-compliance with the principle of legal certainty as well as with the principle of reasonable and legitimate expectations developed in international law. The authors believe that such a relationship may lead to a special new legal basis for claims for damages against the host state. To this end, the authors analyse the French law which, due to the prevailing role of case-law in the system of law establishment and interpretation, has developed a far-reaching and liberal background for designing new standards of liability for damages. In France, the principle of legal certainty takes two general forms, called either principe de sécurité juridique or principe de la confiance légitime. These principles are very often defined by reference to the doctrine and case-law as the right of any individual to legal protection in relation to a loss suffered because of the state authorities' actions, a loss which is a consequence of an unexpected change in a previous regulation by such authorities ${ }^{1}$. Therefore, according to judgement Total v. Argentina ${ }^{2}$, it is assumed that the principle of reasonable and legitimate expectations is sui generis a reflection of the principle of legal certainty.

A representation of changes in the regulatory environment of wind power plants in Poland together with an analysis of changes in the methods of acknowledgement of liability for damages in French law may result in a very interesting conclusions. The purpose of this paper is to answer the question about a possible application of certain mechanisms characteristic for the French legal system in possible claims related to the case of changes in the regulatory environment of wind power plants in Poland.

\section{Are changes in the energy sector a basis for claims?}

An analysis of the hitherto judgements issued by courts of arbitration ${ }^{3}$ raises the question of whether foreign investors can lodge claims against the Republic of Poland. In the context of the energy sector, what is worth highlighting is

\footnotetext{
C. Brown, The Protection of Legitimate Expectations as A "General Principle of Law": Some Preliminary Thoughts, Transnational Dispute Management, www.transnational-dispute-management.com, March 2009; accessed on 15.01.2018.

2 Total S.A. v. Argentina (27 December 2010), Arb/04/1 ICSID, p. 57, item 129.

3 In particular: Nykomb Synergetics Technology Holding AB v. Latvia (16 December 2003), Arb 118/2001 SCC. or AES Summit Generation Ltd. v. Hungary (23 September 2010), Arb/07/22 ICSID or Electrabel S.A. v. Hungary (30 November 2012), Arb/07/19 ICSID.
} 
a possible violation of the Energy Charter Treaty ${ }^{4}$ in respect to the standard of fair and equitable treatment ${ }^{5}$. Yet, in fact, the national natural gas market remains highly regulated despite the assurances that it will be freed. Simultaneously, when it comes to the adoption of the Act on Investments in Wind Power Plants in $2016^{6}$ (which substantially changes the manner of taxation and location of wind power plants), there are still doubts as to whether or not the principle of reasonable and legitimate expectations has been violated.

With regard to the first issue, it should be noted that in the light of Art. 45.1 of the Energy Law Act", "Energy companies specify tariffs for gas fuels or energy as per their respective economic activities..." Those tariffs are subject to approval by the Energy Regulatory Office President. Such a mechanism is supposed to protect recipients of social and welfare services ${ }^{8}$. At the same time, the legislators provide for the possibility of exemption from the said obligation if an energy company operates an economic activity under the circumstances of competition (Art. 49 of the Energy Law Act). Such an expectation was associated with the assurances of the Energy Regulatory Office President with respect to gas price liberalisation for all its recipients. The basis for this expectation was primarily the Communication of the Energy Regulatory Office President No. 21/20139. In January 2013, by publishing the "Roadmap of Gas Price Liberalisation"10, the Energy Regulatory Office President emphasised that price liberalisation for households would be introduced on 1 January 2016. However, this promise has not been kept either ${ }^{11}$.

$4 \quad$ The Energy Charter Treaty and the Energy Charter Protocol on Energy Efficiency and Related Environmental Aspects, drafted in Lisbon on 17 December 1994 (Polish legislation: Dz.U. 2003.105.985 dated 200/6/17).

5 To decide whether the principle of reasonable and legitimate expectations has been violated, one has to take into account three core determinants: a promise of the state resulting in liability for damages; a reasonable and legitimate expectation based on an objective evaluation; and a decision to proceed with the investment if two previous determinants are in place; cf. M. Jeżewski, Międzynarodowe prawo inwestycyjne, C.H. Beck, Warszawa 2011, p. 252.

6 Dz.U. 2016.961.

7 Dz.U. of 2006 No. 89, item 625, as amended.

8 M. Swora, Z. Muras, Prawo energetyczne. Komentarz, Wolters Kluwer, Warszawa 2010, p. 1009.

9 Communication of the Energy Regulatory Office President No. 21/2013 on the schedule of exemption of energy companies, Warsaw, 22 July 2013.

10 Energy Regulatory Office President, Mapa drogowa uwolnienia cen gazu ziemnego, Warszawa 2013.

11 M. Krzykowski, Demonopolizacja rynku obrotu gazem ziemnym w Polsce, in: S. Dudzik, B. Iwańska, N. Półtorak (eds.), Inteligentna i zrównoważona gospodarka sprzyjająca wła- 
Therefore, what is confusing is whether or not the principle of reasonable and legitimate expectations, originating from the standard of fair and equitable treatment (Art. 10.1 of the Energy Charter Treaty) ${ }^{12}$, has been violated in the case in question. Their source is the communication of the President of the Energy Regulatory Office - the central body of state administration. Although this communication is not a source of law, it accounts for certain soft law. After all, when the requirements for issuing a decision on price liberalisation as per the communication are complied with, it seems that such a decision will in fact be made within reasonable and legitimate expectations. However, on the other hand, economic operators joining the investment were aware of the fact that the Polish gas market was highly regulated. Thus, they were familiar with the regulatory environment (and related risks) in which they were to operate their economic activity. In addition, the issue of damage or losses suffered as a result of the regulator having not fulfilling its commitment may also be problematic. In particular, it will be difficult to estimate the actual value of such damage or loss. Therefore, an action based on an alleged violation of reasonable and legitimate expectations (under international investment law) in relation to liberalisation of electricity prices in the Polish natural gas market may prove groundless.

Similar doubts in the context of the principle in question are raised by the adoption of the Act of 2016 on Investments in Wind Power Plants. However, in this case, it seems more appropriate to apply a concept related to the principle of reasonable and legitimate expectations, namely the principle of ensuring a stable and predictable legal framework. It is based on the presumption that the investor deciding to invest takes into account the legal situation of the host state, bearing in mind that it will not change drastically to the investor's detriment ${ }^{13}$.

One of the fundamental disputable elements in the case in question is the manner of calculation of tax levied on wind power plants. Prior to the adoption of that Act, tax on real estate applied only to the foundations and the tower of the turbine, which accounts for less than $20 \%$ of the wind power plant in total, and the value of only those two components were subject to taxation. Nonetheless, as a result of the legislative changes, a structure has been given a new definition. In practice, it meant that wind power plants mentioned in the appendix to the Construction Law Act are subject to taxation on their full value,

czeniu społecznemu - wyzwania dla systemów prawnych Unii Europejskiej i państw członkowskich, C.H. Beck, Warszawa 2017, pp. 248-250.

12 Cf. Biwater Gauff Ltd. v. Tanzania (24.07.2008), Arb/05/22 ICSID, item 602.

13 M. Jeżewski, op. cit., p. 255. 
without division into structural and non-structural components. Therefore, tax has increased almost fourfold.

Referring the above facts to the standard of fair and equitable treatment, it has to be highlighted that so far companies investing in wind power plants have been able to determine whether the investment would be profitable for them. Before the Act on Investments in Wind Power Plants entered into force, tax payers were aware of the applicable tax on real estate which, and one should bear it in mind, is not the only financial burden to be borne while implementing such a complex investment. For that reason, the question arises whether the reasonable legislator put the taxpayer in a situation whose the latter was not able to foresee while planning and clearing the investment. We believe that, in a sense, this is the case. What is more, it seems that the legislator itself was not completely aware of the consequences of these provisions. The foregoing results from the bill of 16 June 2017 on amending the Renewable Energy Act and Other Acts ${ }^{14}$, in which the Minister of Energy indicates that "the bill introduces solutions which will result in a change in the rules for taxation of wind power plants with tax on real estate levied pursuant to the Act of 12 January 1991 on taxes and local fees (Dz.U. of 2016, item 716, as amended). The purpose of those changes is to bring back the legal status to the extent from before the changes introduced by way of the Act on investments in respect of wind power plants". The Minister of Energy further argues that although in the case-law of administrative courts there has begun to form a trend in contradiction to the theses proposed in the said complaint, it is, i.a. this incident that necessitates an immediate amendment to the Act on Investments in Wind Power Plants and to the Construction Law Act in order to resolve doubts as to the unexpected by the legislators consequences of implementing the Act on Investments in Wind Power Plants and amending the provisions of law regarding wind power plants ${ }^{15}$. Hence, it is difficult to consider the actions of the state as the lawmaker to be fully reasonable since its intent was not explicitly a change in the manner of taxation of wind power plants. The authors believe that, in this regard, the state may violated the constitutional principle of citizens' trust in the state. If, after all, the legislators intended otherwise, the state should immediately remedy that error. Meanwhile, after more than a year from the entry of the provisions in question into force, they still apply to investors.

14 The bill was available at http://legislacja.rcl.gov.pl/projekt/12299905; accessed on 12.11.2017.

15 Cf. http://legislacja.rcl.gov.pl/projekt/12299905/katalog/12442263\#12442263; accessed on 12.11.2017. 
At the same time, it has to be highlighted that from the perspective of a stable and predictable legal framework, an investor has to be aware that when starting a business in a given country, the law in that country may change depending on circumstances and needs. As noted by the Court of Arbitration in Enron v. Argentina, the requirement of stability may not result in freezing the legal system or depriving the state of its regulatory competence ${ }^{16}$. However, due to a drastic change in the investor's situation, which in practice very often means no return on investment, one may opine that the aforementioned standard has also been violated.

\section{Reform to the French Civil Code and new liability for damages}

The changes in the legislative environment in Poland described above give rise to a reflection on possible actions aimed at compensating damage and losses suffered by investors investing in wind farms. To this end, the authors resort to the French doctrine and case-law, where the principles of liability for damages are far more developed than in Poland.

First of all, the French legal system was substantially amended when French Civil Code, was changed by Ordinance No. 2016-131 on 10 February 2016. In the French doctrine ${ }^{17}$, it has been claimed for many years that globalisation leads to a situation where legal systems begin to compete with each other, which may result in investors moving from one system to another. This process has been additionally strengthened by the Rome I Regulation regarding the applicable law for contractual obligations ${ }^{18}$ which introduced the fundamental principle that a contract is subject to the law chosen by the parties. The last main reason for the reform to the French civil code was the fact that numerous states inspired by the Napoleonic Code, changed them long time ago by aligning with the process of dematerialisation and virtualisation of economic life ${ }^{19}$.

In accordance with the new Civil Code, the notion of damage in France has not been legally defined, just like in Poland. However, in the French doctrine, it is

16 Enron Corporation Ponderosa Assets L.P. v. Argentina (22/05/2007), Arb/01/3 ICSID, item 261.

17 Y. Lequette, Recodification civile et proliferation des sources internationales, in: J. Carbonnier (ed.), Le Code cvil 1804-2004. Livre du Bicentenaire, Litec, Paris 2004, p. 171.

18 Regulation (EC) No. 593/2008 of the European Parliament and of the Council of 17 June 2008 on the law applicable to contractual obligations (Rome I).

19 More in M. Mariański, M. Lemonnier, Podstawowe założenia i cele reformy francuskiego kodeksu cywilnego z 2016 roku, in: E. Plywaczewski, J. Bryk (eds.), Meandry prawa-teoria i praktyka. Księga jubileuszowa prof. M. Goettela, WSPol, Szczytno 2017, p. 295. 
unquestionable that civil liability has developed on the basis of criminal liability. Essential for the evolution of the concept in question are two fundamental articles of the French Civil Code of 1804, namely Art. 1382 and 1383. Art. 1382 states that every action of man whatsoever which occasions injury to another, binds him through whose fault it happened to reparation thereof. Art. 1383 clarifies that everyone is responsible for the damage of which he is the cause, not only by his own act, but also by his negligence or by his imprudence. Further evolution of liability for damages resulted in gradual replacement of the principle of guilt with the principle of risk. This evolution contributed to the development of new forms of liability for damages with much less significance of the type of damage and the guilt of a culprit ${ }^{20}$.

The main role in the development of new forms of liability for damages was played by the law of 2 February 1995 (loi Barnier) which substantially changed the environmental liability policies by extending the scope of liability to future events. This law stated that preservation of natural resources is in the general interest and falls into the strategy of long-term development, taking into account the interests of future generations. Therefore, in the light of current scientific and technological knowledge, uncertainty should not delay the adoption of effective and proportionate measures to avoid the risk of serious and irreversible damage within economically acceptable costs. The aforementioned change in the law triggered the development of jurisprudence in respect of future damage (préjudice futur) or even possible damage (préjudice éventuel), meaning such damage where one's property or interest would be materially compromised as a result of certain actions, though with consequences in the future ${ }^{21}$. Such damage should be certain (or at least highly probable) and, when it comes to claims for damages in the energy sector, one should be able to estimate its value. Since the adoption of the said 1995 law, a compensable nature has been given to the so-called loss of opportunities if such loss of opportunities regards real and certain issues where a lost opportunity had a certain value itself $\mathrm{f}^{22}$.

The new French Civil Code in articles 1231 and 1240 not only did not prevent the development of such forms of liability, but also allowed for their further evolution.

20 Y. Laquette, Ph. Simler, F. Terré, Droit civil. Les obligations. $10^{\mathrm{e}}$ ed. Dalloz, Paris 2009, p. 695 .

21 More in M. Mariański, M. Zielińska, Pojęcie szkody przyszłej (préjudice futur) w prawie francuskim. Rozważania na tle polskich uregulowań prawnych, Studia Prawnoustrojowe 2015/28, p. 143.

22 Y. Laquette, Ph. Simler, F. Terré, op. cit., pp. 714-715. 


\section{Possibility of using the concept of future damage in the energy law}

The possibility of applying the private and legal construct of future damage to energy law, which generally is of a regulatory nature, is an example of the mutual interaction between private law and public law, as well as between international law and domestic law ${ }^{23}$.

The lack of legal certainty resulting from radical changes in the legislation in the energy sector may lead to future damage from the perspective of energy companies implementing investments prior to those changes. What is significant, future damage in the context of the French law is closely associated with the risk of its occurrence ${ }^{24}$. The employment of the construct of possible damage may lead to "preventive" damages based solely on the actual risk of damage, which made it necessary - especially in the era of the development of the said environmental protection law - to reflect on this topic in doctrinal terms. Future damage and possible damage are forms of expectable damage, and for entities investing in the energy sector, it is damage that should be noted while planning an investment. A problem for courts when estimating its extent may be the evaluation of certainty of ROI if no changes in legislation regarding the sector concerned are introduced. In other words, it is not clear how to measure possible profits of those investments should no regulatory changes concerning wind power plants in Poland be introduced. Referring here to the concept of the legitimate and reasonable expectations would still force courts to analyse and evaluate a degree of certainty of ROI every single time. However, on the other hand, the French doctrine one should focus more on compensation of the very risk of such damage ${ }^{25}$. Thus, in the French law, two general types of future damage are singled out. The first one is a situation where the risk of damage is known and certain, and the second one involves a situation where the risk is indeed identifiable, but theoretically difficult to be explained in detail and estimated.

The first situation concerning the risk of damage that is certain may be associated with the actual circumstances in which the entity was guaranteed by the host state a market energy price level pre-defined by the legislature.

23 R. Schulze, La réforme du droit des obligations en France, in: R. Schulze, G. Wicker, G. Mäsch, D. Mazeaud (eds.), La réforme du droit des obligations en France, SdLC, Paris 2015, p. 11.

24 P. Jourdain, Comment traiter le dommage potentiel?, Responsabilité civile et assurances, Mars 2010/3, dossier 11, p. 40.

25 F. Terré, Pour une réforme du droit de la responsabilité civile, Dalloz, Paris 2011, p. 15. 
A similar situation already occurred in judgements of international courts of arbitratio ${ }^{26}$. Though, in the case in question, the court acknowledged that a given legal system is constructed in a certain way, it does not mean that it ensures the full permanence of solutions arising there from. Thus, the changes introduced by the defending state in the system of remunerating electricity generators did not constitute, in the court's opinion, a violation of the principle of reasonable and legitimate expectations. The authors believe that this ruling could also be an effect of the imprecise wording of the legal basis for claims for damages since, for instance, French courts often accept lawsuits where a certain nature of risk is proven, using primarily "preventive" sanctions to avoid further damage to the entity. Predominantly, said sanctions take the form of monetary compensation for expenditures incurred to cover actions and measures aimed at preventing future damage or at minimising deterioration of its consequences in the future. For wind power plants, such expenditures can be associated with, for example, their closing or dismantling or with their adaptation to new technological parameters. It is worth noting that the new Art. 1251 of the French Civil Code introduced in $2016^{27}$ says that expenditures incurred to prevent direct or further damage, or to minimise deterioration of its consequences, are to be compensated if only they are reasonable expenditures.

The French case-law in that regard has not had a uniform interpretation system in place yet; on one hand, courts can - like in the judgement of the Court of Appeal in Paris from 2008 - award damages to people removing asbestos who exercised their right to retire earlier, having agreed at the same time to a lower pension ${ }^{28}$. In this judgement, the court found that damage constitutes not so much a specific expense as the reduction of a future benefit, which when it comes to claims for damages in the energy sector would be a very useful construct. However, on the other hand, the French Supreme Court (Cour de Cassation) in its judgement from $2006^{29}$ regarding cardiac pacemakers refused to award damages by claiming that possible damage was only a possibility and it is doubtful whether such risk can be proven ${ }^{30}$.

Hence, the French case-law seems to confirm that as a rule, the very risk of damage in the form of, for example, lower profitability of energy investments is

26 As, for example, in the case of the dispute between Total S.A. v. Argentina.

27 Pursuant to Act No. 2016-1087 of 8 August 2016 pour la reconquête de la biodiversité, de la nature et des paysage (JORF $n^{\circ} 0184$ dated 9/8/2016).

28 CA Paris, 18 September 2008, RG n ${ }^{\circ}$ 07/00454 : JurisData n 2009-003329 ; D. 2009, p. 2091.

29 Cass. 1re civ., 19 déc. 2006, nº 05-15.719 : JurisData n² 2006-036698; JCP G 2007, II, 10052.

30 P. Jourdain, op. cit., p. 43. 
not sufficient since it has to display a sufficient degree of certainty and a cause and effect relationship. Such a relationship is difficult to estimate when, for instance, energy prices are modelled by the market through the cost of regulated prices because it is difficult to predict - especially in an era when renewable energy sources are being depleted - what the future price will be, thus what the actual extent of the damage in question actually is. Damage can also be in the present or future, but always certain enough to be reasonably estimated. It is evident in the French doctrine that the development of liability for damages may not lead to awarding damages exclusively for the risk of damage only, but rather for risk-related expenditures. Such expenditures, which for the wind power sector could be substantial, should concern real and serious risks and should be reasonable and necessary to prevent them.

As far as this article is concerned, of interest seem to be occasional statements that risk on its own may be the basis for awarding damages as compensation for either economic damage or moral damage related to such risk with a relevant causal link. In particular, compensation for future economic damage might be of interest to investors in the energy sector since changes in the law may quickly decrease the location value of a certain real estate or of the plots of land on which the wind power plant was erected ${ }^{31}$.

In the event of damage of uncertain risk, the fundamental question is whether it will be possible to invoke liability other than a strictly "preventive" one. However, some experts in the French doctrine allow for the possibility of basing new "preventive" liability on the traditional civil-law foundations ${ }^{32}$. Such liability would be possible by referring to the prevention principle and the precautionary principle originating from the environmental protection law, which, in turn, would allow courts to issue rulings also in case of doubt as to the nature of risk. Interestingly, French courts applied the same line of reasoning, for instance in a judgement of the Versailles Court of Appeal dated 4 February $2009^{33}$. In that judgement, even though it was about damage associated with the operation of a mobile transmitter, the court noted that uncertainty as to the scope of future damage should not be an obstacle to its subjective assessment by the court. Therefore, it seems that it is possible, at least theoretically, that apart from typical damages, preventive measures would be awarded to supplement

31 Court of Appeal in Paris in its judgement dated 12 September 2008, CA Paris, 12 September 2008, RG n 07/05802 : D. 2008, p. 2429.

32 F. Terré, op. cit., p. 185.

33 CA Versailles, 4 févr. 2009, $n^{\circ}$ 08/08775 : JurisData $n^{\circ}$ 2009-000135. 
a given judgement ${ }^{34}$. The foregoing renders the aforementioned analysis even more interesting from the perspective of entities seeking damages for breaking the principle of legal certainty in respect of their investments.

\section{Conclusions}

The adoption of the Act on Investments in Wind Power Plants in 2016 in Poland, which changed the manner of calculating tax on real estate levied on wind power plants, triggered a heated discussion about the principle of legal certainty and the principle of reasonable and legitimate expectations originating from it. Before this Act, real estate tax was charged only on the foundations and the tower, and after its adoption, the entire investment was taxed without breaking it down into structural components and non-structural ones.

The violation of the principle of legal certainty that may be claimed in that regard inclined the authors to reach a conclusion about the possible use of the French doctrine and case-law in respect of new forms of liability for damages. Thus, based on the example of the French jurisprudence, it seems viable also in the polish market to claim reimbursement for expenditures incurred to prevent direct or further damage or to minimise deterioration of its consequences if only such expenditures were reasonable. In addition, in accordance with the aforementioned legislation, it is possible to claim damages on account of decreasing future compensation payable to a given entity after the implementation of an investment. Eventually, it seems applicable to the case of wind power plants in Poland, where the jurisprudence is less developed in this field than in France, to compensate future economic damage if, as a result of legal changes, there is a change in the location value of a given real estate or of the plots of land on which a given wind power plant was erected. The intention of the authors was therefore to present, based on a comparative approach, new potential grounds for claims for damages in the analyzed field, that may be an interesting perspective for the further research.

34 P. Jourdain, op. cit., p. 45. 


\section{References}

\section{Legal Rulings}

AES Summit Generation Ltd. v. Hungary (23 September 2010), Arb/07/22 ICSID.

Electrabel S.A. v. Hungary (30 November 2012), Arb/07/19 ICSID.

Enron Corporation Ponderosa Assets L.P. v. Argentina (22/05/2007), Arb/01/3 ICSID.

FR: CA Paris, 12 September 2008, RG n 07/05802 : D. 2008, p. 2429.

FR: CA Paris, 18 September 2008, RG nº 07/00454 : JurisData n²009-003329 ; D. 2009, p. 2091.

FR: Cass. 1re civ., 19 déc. 2006, $n^{\circ}$ 05-15.719 : JurisData ${ }^{\circ}$ 2006-036698; JCP G 2007, II, 10052.

FR: CA Versailles, 4 févr. 2009, nº 08/08775 : JurisData n 2009-000135.

Nykomb Synergetics Technology Holding AB v. Latvia (16 December 2003), Arb 118/2001 SCC.

Total S.A. v. Argentina (27 December 2010), Arb/04/1 ICSID.

\section{Laws}

Energy Charter Treaty and the Energy Charter Protocol on Energy Efficiency and Related Environmental Aspects, drafted in Lisbon on 17 December 1994 (Polish legislation: Dz.U. 2003.105.985 dated 200/6/17).

FR: Act No. 2016-1087 of 8 August 2016 pour la reconquête de la biodiversité, de la nature et des paysage (JORF $n^{\circ} 0184$ dated 9/8/2016).

Komunikat Prezesa Urzędu Regulacji Energetyki nr 21 /2013 w sprawie harmonogramu zwolnienia przedsiębiorstw energetycznych posiadających koncesje na obrót paliwami gazowymi, Warszawa, 22 lipca $2013 \mathrm{r}$.

Ustawa z dnia 10 kwietnia 1997 r. - Prawo energetyczne (Dz.U. z 2006 r., nr 89, poz. 625).

Ustawa z dnia 20 maja 2016 r. o inwestycjach w zakresie elektrowni wiatrowych (Dz.U. z 2016 r., poz. 961)

\section{Literature}

Brown Chester, The Protection of Legitimate Expectations as A "General Principle of Law": Some Preliminary Thoughts, Transnational Dispute Management, www.transnational-dispute-management.com, March 2009; accessed on 15/01/2018.

Jeżewski Marek, Międzynarodowe prawo inwestycyjne, C.H. Beck, Warszawa 2011.

Jourdain Patrice, Comment traiter le dommage potentiel?, Responsabilité civile et assurances $\mathrm{n}^{\circ}$ 3, Mars 2010, dossier 11.

Krzykowski Michal, Demonopolizacja rynku obrotu gazem ziemnym w Polsce, in: Sławomir Dudzik, Barbara Iwańska, Nina Półtorak (eds.), Inteligentna i zrównoważona gospodarka sprzyjajaca właczeniu społecznemu - wyzwania dla systemów prawnych Unii Europejskiej i państw członkowskich, C.H. Beck, Warszawa 2017.

Laquette Yves, Simler Philippe, Terré François, Droit civil. Les obligations, 10e ed., Dalloz, Paris 2009.

Lemonnier Mariola, Mariański Michal, Podstawowe założenia i cele reformy francuskiego kodeksu cywilnego z 2016 roku, in: Emil Pływaczewski, Janusz Bryk (eds.), Meandry prawa - teoria i praktyka. Księga jubileuszowa prof. M. Goettela, WSPol, Szczytno 2017. 
Lequette Yves, Recodification civile et proliferation des sources internationales, in: Jean Carbonnier (ed.), Le Code civil 1804-2004. Livre du Bicentenaire, Litec, Paris 2004.

Mariański Michal, Zielińska Magdalena, Pojęcie szkody przyszłej (préjudice futur) w prawie francuskim. Rozważania na tle polskich uregulowań prawnych, Studia Prawnoustrojowe 2015/28

Schulze Reiner, La réforme du droit des obligations en France, in: Reiner Schulze, Guillaume Wicker, Gerald Mäsch, Denis Mazeaud (eds.), La réforme du droit des obligations en France, SdLC, Paris 2015.

Swora Mariusz, Muras Zdzisław, Prawo energetyczne. Komentarz, Wolters Kluwer, Warszawa 2010.

Terré François, Pour une réforme du droit de la responsabilité civile, Dalloz, Paris 2011.

Michał KRZYKOWSKI

Michał MARIAŃSKI

\section{BRAK ZAPEWNIENIA PEWNOŚCI PRAWNEJ JAKO PRZESŁANKA ROSZCZEŃ ODSZKODOWAWCZYCH. ANALIZA PRAWNO-PORÓWNAWCZA}

(Streszczenie)

Niniejszy artykuł dotyka problemu zależności między brakiem pewności prawnej i wynikającymi z niej uzasadnionymi i rozsądnymi oczekiwaniami a potencjalnymi roszczeniami odszkodowawczymi podmiotów prywatnych względem państwa goszczącego. Impulsem do podjęcia takiego tematu badawczego były zmiany w sposobie regulacji inwestycji w elektrownie wiatrowe w Polsce, które w sposób znaczący wpłynęły na opłacalność tego typu przedsięwzięć. Przedstawienie zmian w otoczeniu regulacyjnym elektrowni wiatrowych w Polsce w zestawieniu z analizą zmian w sposobie generowania odpowiedzialności odszkodowawczej w orzecznictwie francuskim może prowadzić do bardzo ciekawych wniosków tak dla polskiego ustawodawcy, jak i dla podmiotów sektora prywatnego w energetykę wiatrową zaangażowanych. Orzecznictwo oraz doktryna francuska mogą dostarczyć bowiem szerszego spektrum potencjalnych podstaw prawnych dla roszczeń odszkodowawczych w tym zakresie i stanowić impuls do dalszej pogłębionej analizy.

Słowa kluczowe: elektrownia wiatrowa; szkoda przyszła; prawo francuskie; odszkodowanie; pewność prawna 
